\title{
TAKT TIME PLANNING IN PORSCHE CONSULTING, THE BOLDT COMPANY AND VEIDEKKE
}

\author{
Matthias Helgi Gardarsson ${ }^{1}$, Ola Lædre ${ }^{2}$ and Fredrik Svalestuen ${ }^{3}$
}

\begin{abstract}
In recent years takt time planning has been a more and more utilized method in construction projects. In 2010 the Norwegian contractor Veidekke started their first takt project and have since carried out several projects with the method. The results of these has been wavering from breakdowns of the takt system to great success. It is therefore interesting to see how takt is used by different companies internationally and which experiences these have compared to Veidekke.

Through literature reviews, interviews and case studies the paper looks at takt as practiced by Porsche Consulting, The Boldt Company and Veidekke. Their practical applications have a lot in common, but are distinguished - among other things - by the way to involve subcontractors, the types of projects that they use takt on, and how they divide the project into zones. Currently, takt seems to be dependent on key persons familiar with the method, and there is a need for a guideline for takt so more projects can benefit from use of the method.
\end{abstract}

\section{KEYWORDS}

Takt time planning (TTP), lean construction, production planning, work flow, buffer

\section{INTRODUCTION}

The contractor Veidekke has in recent years used takt time planning in some projects. Takt is a relatively novel method for the Norwegian construction industry, and Veidekke is one of few contractors that have applied it. The practice of takt varies between countries, companies and even within the same company. The method seems to depend on key persons in the project that are familiar with the method. To some extent, the management staff and the foremen on-site have been the same across takt projects. However, the results of using takt have varied between the projects. Some projects have experienced success, and some have experienced failure-like outcomes. Based on that, there is a need to find out

1 MSc, Student, Department of Civil and Environmental Engineering, NTNU - Norwegian University of Science and Technology, Trondheim, Norway, +4790120191, mhgardarsson@gmail.com

2 Professor, Department of Civil and Environmental Engineering, NTNU, Trondheim, Norway, +4791189938, ola.ladre@ntnu.no

3 Researcher, Department of Civil and Environmental Engineering, NTNU/Department Manager, Veidekke, Trondheim Norway, +4798673172, fredrik.svalestuen@ veidekke.no 
how using takt in construction can lead to success. Therefore, this study maps experiences with takt in Norway and abroad. The research questions:

- What types of takt are used today?

- What are the experiences with takt?

The study's novel contribution lies in the comparison of how takt is practiced in by the companies Porsche Consulting, The Boldt Company and Veidekke. Veidekke has cooperated with both Boldt and Porsche Consulting, so their use of takt is known in by Veidekke employees. The paper mainly takes interior work into consideration, even though its also used for concrete and exterior work.

\section{THEORY}

Takt is German for "beat" and refers to the manner takt time planning is carried out in production. Takt is a lean-tool that has a goal to reduce waste and increase value by creating a stable environment for implementing Last Planner (Frandson et al., 2014). Takt was first used in traditional industry, like the automotive industry, where products move down an assembly line with a set takt time at each work station. Each station has to finish their work before the item is moved along to the next work station (Hopp \& Spearman, 2008). Fabrication shops and construction industry are similar because the sequencing and pace of the work is driven by labor instead of machines (Linnik et al., 2013). The difference is that the product in construction is fixed at one place and cannot be sent between the workstations. Instead the workers have to move from station to station, or zone to zone, in a set time followed by a new group of workers. Each group consist of workers of preferably one trade that complete a set of activities without interference from other trades. This is what we call takt. Takt is often illustrated as a train with several wagons moving through a construction site. The wagons are the different groups of workers that complete their set of tasks before moving to the next area followed by another wagon that will complete their set of tasks. Together they make up the train that leaves a finished construction when the last wagon finishes.

Different trades need different time to complete the distinctive zones. For each zone the trades set an upper-bound time they need to complete their activities. Since everyone moves with the same pace some trades will work with lower capacity then what is possible (Frandson et al., 2013). The capacity for each wagon is the amount of work that is possible to do within the takt time with a given number of workers. In takt project most wagons will work under capacity while the bottleneck activities will set the pace. When the takt time is set high many trades will have idle time. If the takt time is low then many trades will have issues finishing on time. This can be solved by increasing or decreasing staffing dependent on of the task is working under and over capacity. Idle crew can work on workable backlogs, rigging, improvement work, etc. For wagons exceeding the takt time they can, in addition to increase crew size, use different means-and-methods, change set-up for the work or increase the use of prefabrication.

Frandson et al. (2015) describe four possible buffers that construction planners can use; time, capacity, space and workable backlogs. Frandson (2015) argues that takt projects can use all except time. This is because the activities in takt are closely connected with little room for adjusting the timetable without interfering with the entire project line. Instead the 
capacity can be adjusted through increasing or decreasing the number of workers in each wagon as described above. Space as a buffer in takt are parts of the zone that are finished by one trade so the following trade can start their work without interfering. This can for example that the first trade has completed three out of four apartments within the takt time. The next trade can start with the three apartments while the first trade completes the last apartment. Some areas are uneven in the amount of work for the different trades. Therefore, it might be better to do these areas off-takt as a workable backlog. Workable backlog can give and receive workers from over- or understaffed zones.

\section{METHODS}

The methods used in this study include a literature review, case studies, interviews and a document study. The paper has a set goal of helping Veidekke to improve on takt time planning. Therefore, most of the research is done on Veidekke's projects to understand how they utilize takt and how it can be improved. Research on Porsche's and Boldt's projects is done in order to compare them with Veidekke's projects.

The existing literature on takt in Norway and abroad is reviewed. The literature review was inspired by Arksey and O'Malley's (2002) paper on scoping studies. Google Scholar, Oria and the IGLC.net were used in this review. Google Scholar has a wide range of papers and is easy to navigate in. It is not the most reliable database, so the sources' reliability was double checked. Oria is NTNU's database with an extensive specter of research papers, articles, books and dissertations. IGLC's web page contains all previous IGLC conference papers and recent research on takt time planning.

The literature review has been conducted to get an overview of the existing literature within takt and answer research questions. Takt is a relative novel method, especially in Norway, so the amount of relevant literature is limited. Abroad The Boldt Company has participated in multiple papers, and Veidekke has in collaboration with NTNU published master thesises and research papers about takt projects. Mordal (2014) wrote about the housing project Horneberg B3 and Smiseth (2013) wrote about the Knowledge Centre at St. Olav's Hospital in Trondheim. In addition to this, Solem (2013) and Andersen (2012; 2013) wrote research rapports about the construction of the Knowledge Centre. Porsche Consulting delivers commercial services with takt to contractors and developers, so literature from them has been hard to find. However, some documents and course presentations from Porsche Consulting have been acquired and used in this paper.

The three companies chosen in this study are Porsche Consulting, The Boldt Company and Veidekke. Porsche Consulting originates from the car producer Porsche. Porsche Consulting provides training and consulting in takt time planning for contractors, but does not conduct construction projects themselves. After being nearly bankrupt in the 1990s, Porsche implemented takt time principles inspired by Toyotas Just-In-Time methods with huge success (Nash, 1996). They did this by manufacturing the cars with a set finishing time for all activities down the assembly line. This increased flow and reduced waste. Porsche transferred this principle from car production to construction projects. By using the same principles of series of set tasks finishing at the same time, with the worker moving around at the building site instead of the car moving down the assembly line, Porsche Consulting achieved a similar success. 
The Boldt Company is an American contractor with over 2000 employees located in multiple states across the US. They offer services like construction management, design, real estate development and technical services. Their department in Sacramento, California is one of the leading construction firms in takt.

Veidekke is one of Scandinavia's largest contractors and property developer with over 8,000 employees. Veidekke has been using takt in some of its projects since the Knowledge Center in Trondheim was built in cooperation with Porsche Consulting in 2010. Since then Veidekke has incorporated takt into its own Lean Construction initiative Collaborative Planning and started a partnership with Boldt where knowledge and experience regarding takt is exchanged. Takt has been implemented in a handful of projects and they are now working on a guideline for use of takt in Veidekke.

These three companies were chosen because they have different approaches to takt, they have come far with takt in their local market, and information was available for both theory and cases. Four cases have been used to illustrate takt in Porsche, Boldt and Veidekke. Three of the selected cases were in Norway and one in the US. In 2010 Porsche Consulting consulted Veidekke in implementing takt in the new Knowledge Center at St. Olav's Hospital in Trondheim, Norway. This was the first takt project for Veidekke and it was therefore heavily influenced by Porsche Consulting and hence defined as a Porsche Consulting project in this study. The project had a budget of 32 million euros, was built over three years and was the first hospital building in the world with passive house standard. Solem (2012), Smiseth (2013) and Andersen (2012; 2013) conducted interviews and research on this project. It has therefore been possible to see what was implemented by Veidekke and Porsche Consulting. The second case was Sutter Health Anderson Luchetti Women's and Children's Center (WCC). It is a nine-story hospital with 242 sleeping accommodations in Sacramento, California and was built with takt by The Boldt Company. The case is described by Linnik (2013). Veidekke's Moholt 50/50 - the third case - was a student housing project with 5 nine-story buildings where every floor, except the main floor and basement, have the exact same design. In addition, a parking basement, a library and a kindergarten were built and the whole project had a budget of 46 million euros. Only the living areas of the student housing was built with takt. The case is scarcely described in the literature and the information largely comes from interviews with key persons in the project. The cases were chosen to exemplify some of the differences found between the methods. While the three other case projects finished several years ago, there have also been done a case study of a project under construction in 2019. The project Nærbyen in Trondheim is a project with apartment and commercial areas, where the interior phase in the apartment's areas are built with takt. The initial findings about takt in Veidekke has been verified through interviews with project managers and foremen at this project.

6 Project managers from Veidekke, 2 project managers from and The Boldt Company, as well as 3 foremen from Veidekke were interviewed. The authors did not find representatives in Porsche willing to be interviewed, but some of the representatives from Veidekke have worked with Porsche in the Knowledge Centre. Most of the interviews were with representatives from Veidekke, who were easy to get in touch with due to geograpichal location. In addition, one of the authors is employed by Veidekke and the main author has had vacation job positions there. The interviews done for this thesis were 
semi-structured and inspired by Yin's (2009) 5 traits of a good interview. The interviews were conducted to supplement and confirm the actual findings from the literature review. This was important since the existing literature is limited and that the method, especially in Norway, where the method so far is used by few people.

\section{RESULTS AND DISCUSSION}

The three methods of takt time planning of Porsche, Boldt and Veidekke have in common that they promote a stable flow in production through clear interfaces between the different activities, predictable task management and a steady number of crew. This section presents the differences between the methods one by one, based on the two research questions about 1) what types of takt are used today and 2) what are the experiences with takt. Finally, the section presents the similarities.

\section{EARLY INVOLVEMENT OF SUBCONTRACTORS DURING PLANNING}

\section{Zoning, sequencing and constraint analysis}

There are different practices on involving the subcontractors between the methods. Porsche has little involvement of the subcontractor early in the planning and scheduling. The general contractor and project manager develop a production schedule with zoning, takt time and trade sequence. Subcontractors gets the chance to adjust the plan late in the process. Porsche has a top-down management approach which is common in industries and German construction projects. This is unlike Norway where a bottom-up version is more common. Boldt and Veidekke involve their subcontractors in planning zones, sequencing activities and constraint analysis. Zones in takt are designated areas where trade activities move through. Constraint analysis identify causes of uncertainties in the workflow of the construction and how this can be solved to improve the reliability of the plan (Shen and Chua, 2005). Involvement in Veidekke and Boldt is done through a series of workshops with the subcontractors and project management before construction starts. Veidekke use their own Lean initiative, Collaborative Planning, to facilitate the planning of takt.

It is believed, especially in Veidekke, that the foremen are the ones that know their field and team best and therefore are most capable to accurately assume work load, decide the optimal trade sequence and predict uncertainties in production. Also Boldt puts great emphasis on making a collaborative environment for planning.

On the Knowledge Center the subcontractor delivered information about expected work load for each area of the project. The project management used this information to divide the project into zones and set the takt time. In Solem's (2012) master theses about the project the participants said that takt in Porsche was not adjusted for Norwegian work culture. They felt ignored in the planning process and meant that the timetable did not take into consideration their actual needs for completing each zone on time. They did not feel any ownership to the plan and did not participate in a constraint analysis which led to problems that could have been avoided (Smiseth, 2013).

A critical success factor for takt time planning is the involvement of subcontractors. Involvement of the subcontractor at Moholt 50/50 created ownership of the plan among the foremen. They managed to sell the plan to their teams and actively contributed in solving problems that appeared throughout the project, often without needing to involve 
the project management. They felt ownership to the plan they participated in making and felt a responsibility to follow it. The predictability of what to do each week and every day combined with the repetitive design of the buildings meant that needed workhours was cut throughout the project. Construction errors were reduced and absence due to sickness almost eliminated.

\section{Takt time and design phase}

Veidekke prefers the takt time as a weekly takt time with start up on Mondays and handover to the next activity on Fridays. This is often a set part of takt in Veidekke and the subcontractor seldom can change this. Boldt and Porsche is more flexible with the length of the takt time for the project, but Boldt let the subcontractor take part in the decision.

In Norway it's normal to procure the subcontractor after getting the project while Boldt does this earlier in the project. This enable Boldt to involve the subcontractor in the design phase. This helps the project designers to find solutions that will make the construction easier to build.

\section{PROJECT TYPES}

\section{Using takt on complex projects}

Veidekke have had success with apartment complexes and student housing when using takt while Boldt and Porsche have had success with more complicated projects like hospitals. Boldt has used takt since the late 2000's and have today a more sophisticated method compared to Veidekke. In Norway takt is a new method that have been used on few projects. The method is therefore unfamiliar for most of the industry.

For takt to become a consistently successful it is vital that more contractors and subcontractors get sufficient training and understanding of the method. It is therefore essential that the project manager uses enough time in the beginning of the project to make sure that all the subcontractor understand the principals and their role in the project. Using the same subcontractors in multiple projects will give benefits for the contractor in the long run. For Veidekke a guideline should also be easy to use and adjust for different projects in such a way that it is possible to use takt without any prior experience.

Veidekke has only implemented takt in interior work and at some degree in exterior work. Porsche and Boldt uses takt for the entire production, which also involves exterior work as well as concrete work.

\section{Varying takt time and zoning throughout the project}

Boldt changes the zoning and takt time depending on the phase they are in. For example, with an office- or hospital building the first phase would be an overhead phase where MEP (Mechanical, Electrical and Plumbing) racks, ductwork and tubes are installed. These activities span over large areas and the zones are therefore large compared to the following phases. A framing phase usually follows with tasks like framing and firestopping which are more labor intensive per square meter of building which means that the zones get smaller or the takt time longer. After this follows a drywall phase and then a finishes phase.

To be able to split the project into phases and do separate takt for each zone you will need more planning and it is more demanding to control during building than project that 
runs with the same zoning and takt time. The benefit is that the trades are given the optimal area to work most efficient.

\section{VARIES TAKT TIME FROM PROJECT TO PROJECT}

Takt time is an essential part of the takt projects. Veidekke use almost exclusively weekly takt time with startup on Mondays and handover on Fridays. They have experienced good results with this at Moholt 50/50 and Nærbyen. The craftsmen highlights predictability with the weekly takt as the biggest advantage with the method. There is always a clear plan for where they are going to be and what is expected to be done.

The weekly takt time also fits well with Veidekke meeting structure in Collaborative Planning which has set meetings throughout the week. In Collaborative Planning there are a series of meetings on different levels of the project hierarchy, at set intervals, with their own agenda for the meeting. The different meetings have different time windows they plan for. Wednesday there is a meeting where the trades have to report if they will finish on time or what they will do to finish on time. One or more wagons within the same trade usually have a team meeting at the start or at the end of a week to discuss next week's work. There are weekly meetings between the foremen in each train and at Nærbyen they have started to take these meetings on the construction site while walking through the zones. Here the foremen talk together, solve problems and adjust ways of production to optimize production in the train. By trains the author means a series of activities that follow each other through certain zones with a set takt time for each zone. In one of the meetings the project management and the foremen of the project meets and discuss the plan for upcoming weeks and problems discovered on the foremen meeting. Here potential changes in the takt can be discussed and agreed upon and problems from the foremen meeting discussed and solved with the project management.

A five-day-cycle that is used by Veidekke leads to large areas of the zones not being under production. For example, will an apartment building with three apartments in each zone have only one apartment in production at any time. This means that only a third of the construction site is under construction at any time. This works as a buffer since it allows the next activity to start in one part of the zone while the previous finishes at another part. This buffer can be avoided to reduce production time and cost by decreasing takt time and the size of the zones, but then the risk of propagating the delay increases.

With a weekly takt time the trades have the option to work overtime in the weekend if they are behind schedule. It is also sufficient time to adjust staffing with status meeting on Wednesdays. With shorter takt time there is less room to adjust for delays. At the same time there is little room for improving takt when you are obliged to plan within one week. There might be projects where another takt time is more ideal, and when takt as a method evolves it might be to smaller more compact zone to ensure that more of the project are under construction at any time.

\section{DIVIDING IN ZONES}

An important part of setting up the takt plan is to divide the project into zones. What criteria this is based on is different for the three companies. Porsche Consulting start their process by identifying areas that are repeatable and non-repeatable. Repeatable areas are for 
example offices, hotel rooms and front claddings while non-repeatable areas can be lobbies, technical rooms and kitchens. The repetitive areas are divided into construction sections, usually floors, and then into smaller subsections if necessary. One subsection can be a set number of hotel rooms. The non-repetitive areas are either used as backlog areas or divided into different types of buildings, e.g. shops, bars and restaurants in a commercial area. Then these areas are further divided into subsections to fit the needed workload into a given takt time. After this the trade sequence is defined before each trade required work duration for the different subsection is calculated. From this the required staffing is calculated to complete the trade on the set takt time.

The Boldt Company base their zoning on the scope of work for each trade. They use a lot of time understanding the scope early on in the project before they start to divide the project into zones and decide the trade sequence and takt time. As mentioned Boldt change their zoning and takt time throughout the project in different phases. To do this it is important to truly understand the scope.

Veidekke use both scope of work and architecturally defined areas to divide their project. Architecturally defined areas are naturally defined areas in the project like floors, classrooms or areas within fire walls. On Moholt 50/50 it was natural to divide the project into floors since each floor was identical so the workload for the different trades would be the same every week. Other projects, like Nærbyen, have divided the project into floors for the different towers of the building. Here the apartments within the towers are different and therefore the scope varies from floor to floor. Variation in workload means that staffing has to be adjusted from week to week. This can reduce the predictability for the craftsmen and frequent transfer of staffing will reduce the continuous improvements gained by having steady teams. This also reduce the craftsmen ownership to their wagon's completion time in the project. The benefit of having areas defined by architecturally defined zones is that it is more transparent and therefore easier for everyone to understand the zoning. It also makes rigging and transportation easier. By having all production in one floor workers don't have to move up and down with materials and equipment.

\section{SIMILARITIES}

All three companies use multiple trains in their projects. When there are multiple trains this means that there are two or more unconnected series of activities that move through a separate area of the project. This usually is done in project where the content of the building varies greatly from area to area which makes it difficult to balance the workflow. This can for example be buildings with large amount of technical rooms, wet rooms, laboratories or office areas. It is also used in big projects where it makes sense to use multiple trains instead to increase workflow. In Veidekke there is a split opinion among the project leaders about using multiple trains. Some think multiple trains should be used depending on the building type. Others believes this will create more variation in workload which can accumulate at times and create delays. The chance of total halt is reduced since the risk is divided between the trains, but it is more demanding for the project management to control the production.

The interview objects said that buffer for takt projects often are workable backlogs, overstaffing and using areas as buffers. Also, Frandson (2015) describe workable backlogs, overstaffing and areas as buffers that can be used in takt project. Veidekke always start 
their takt projects with overstaffed wagons so it can withstand problems that haven't been detected and solved in the constrain analysis. After a while when the initial problems are solved, and the workflow is stabilized the staffing is reduced. The extra staff is sent to other wagons in the train, workable backlogs or other projects.

In Moholt 50/50 there was an increase in work flow throughout the whole project as the workers learnt better ways to streamline the production. The extra work hours that were gained was used on workable backlogs that where not planned in takt. When there was delays workers from workable backlogs was called in to help. Moholt 50/50 got issues in the end because the project management and subcontractors used to much time and focus on planning and following the takt that the backlog areas was neglected.

Takt is especially vulnerable for delays in the plan during construction compared to traditional planning. There are direct links between all the activities so delays in one can lead to delays for all the following activities if measures are not implemented. This means that drawings and materials must be delivered on time in addition to sufficient staffing to complete the task. A change in the timetable must be approved by all subcontractors because it affects everyone. When problems occur in one of the wagons it's hard to change the plan much more than one or two days without it having negative impact on the following wagons. Postponing the deadline for a wagon is therefore not an option.

All three companies involve their subcontractor during production to adjust the schedule for changes. Porsche Consulting uses a takt control board to control production. Several of these boards are placed around the project with updated information about the HSE-status, construction sequence and completion status for the different wagons. The foremen and project managers have frequent meetings by the boards to update and give status. If they expect to finish on time the activity is marked in green, if it will be finished with extra work/overtime the activity is marked in orange, and if the wagon can only be finished through non-planned activities and extra cost the activity is marked with red. Porsche Consulting also have a defined restart system with the objective to come back to the planned takt after shutdown as soon as possible. The site manager and subcontractors identify all delayed activities and work required for each trade to get back on the plan. From this a new plan is made. Veidekke used the takt control board in the Knowledge Centre but have since gone away from this method. Instead they use methods from Collaborative Planning to control and adjust production in their takt project. Boldt have daily check-ins and weekly meetings to discuss the progress for each trade and systems in place for restarting the takt plan. Takt is, when implemented right, a self-regulating transparent system, meaning that the subcontractors are controlling and pushing each other to complete on time more compared to projects with more traditional scheduling. The transparency also makes it easy to control progress and quality of work. The activities that are struggling are spotted early and measures to increase their productivity can be implemented.

\section{CONCLUSION}

The paper answers two research questions; what types of takt are used today and what are the experiences with takt. The paper looks at takt time planning in Porsche Consulting, The Boldt Company and Veidekke. Their application differs regarding what types of projects 
where they use takt, if they use takt on the entire project or not, and how the subcontractors are involved. Subcontractor involvement is - according to many of the interview objects one important reason for success with takt time planning. Boldt changes their zones and takt time through different phases of the project, while Veidekke uses the same weekly takt time for all their projects. The companies base their zoning on different criteria. Veidekke and Boldt run their own projects, while Porsche Consulting only takes the role as a consultant. Table 1 illustrates the differences.

Table 1: Illustration of differences between application of takt-time planning

\begin{tabular}{cccc} 
& Porsche & & The Boldt \\
Consulting & & Veidekke \\
$\begin{array}{c}\text { Involving subcontractors early in } \\
\text { production planning of: }\end{array}$ & & & \\
\hline $\begin{array}{c}\text { Zoning, sequencing activities and } \\
\text { constraint analysis }\end{array}$ & No & Yes & Yes \\
\hline $\begin{array}{c}\text { Takt time and design phase } \\
\text { Type of projects }\end{array}$ & No & Yes & No \\
\hline $\begin{array}{c}\text { Using takt successfully in complex } \\
\text { projects }\end{array}$ & Yes & Yes & No \\
\hline $\begin{array}{c}\text { Varying takt time and zoning } \\
\text { throughout the project }\end{array}$ & No & Yes & No \\
\hline Uses takt on the entire project & Yes & Yes & No \\
\hline Varies takt time from project to project & Yes & Yes & No \\
\hline Divide zones primarily based on: & Repeatability & Scope of work & $\begin{array}{c}\text { Architecturally } \\
\text { defined areas }\end{array}$ \\
\hline Type of business & Consultant & Contractor & Contractor \\
\hline
\end{tabular}

There are also many similarities between the application of takt-time planning. All three companies use multiple trains in their projects, they involve subcontractors in planning and rescheduling during production, and they use much of the same types of buffers.

To let more projects benefit from takt time planning, its necessary to develope guidelines. With guidelines, the use of takt will not depend on individual persons familiar with the method. The guidelines should contain principles for takt and examples from practical application without being too detailed. The guidelines should be flexible enough to let the method be adjusted to each individual project.

\section{REFERENCES}

Andersen, L. (2012). Organisering av prosjekterings- og byggeprosessen St. Olavs hospital, Kunnskapssenteret [Organisation of design and construction process St. Olavs hospital Knowledge Centre], 1st Ed., Helsebygg Midt Norge, Veidekke og YIT, Trondheim, Norway 
Andersen, L. (2013). Samhandling i prosjektering og bygging. Kunnskapssenteret. St. Olavs Hospital [Cooperation in design and construction. Knowledge Centre. St. Olavs Hospital], 1st Ed., Helsebygg Midt Norge, Veidekke og YIT, Trondheim, Norway

Arksey, H., \& O'Malley, L. (2005). Scoping studies: towards a methodological framework. International journal of social research methodology, 8(1), 19-32.

Fiallo, M. and Howell, G. (2012). "Using Production system Design and Takt Time to Improve Project Performance." In Proceedings of the 20th Annual Conference of the Inerantional. Group for Lean Construction, San Diego, CA, USA.

Frandson, A., Berghede, K., \& Tommelein, I. D. (2013, August). Takt time planning for construction of exterior cladding. In Proceedings of the 21st Annual Conference of the International Group for Lean Construction. Fortaleza, Brazil.

Frandson, A., Berghede, K., \& Tommelein, I. D. (2014, June). Takt-time planning and the last planner. In Proceedings of the 22nd Annual Conference of the International Group for Lean Construction. Group for Lean Construction (pp. 23-27).

Frandson, A. G., Seppänen, O., \& Tommelein, I. D. (2015). Comparison between locationbased management and takt time planning. In Proceedings of the 23rd Annual Conference of the International Group for Lean Construction (pp. 28-31). Perth, Australia.

Linnik, M., Berghede, K \& Ballard, G. (2013). An experiment in takt time planning applied to non-repetitive work. In Proceedings of the 21th Annual Conference of the International Group for Lean Construction. Fortaleza, Brazil.

Nash, N. C. (1996). Putting Porsche in the Pink. New York Times accessed February 16, 2017.

Shen, L. J., \& Chua, D. K. (2005). Key constraint analysis: achieve lean processes with the application of TOC. In Construction Research Congress 2005: Broadening Perspectives (pp. 1-10).

Smiseth, S. (2013). Taktplanlegging, en god måte for å gjennomføre produksjon $i$ byggeprosjekter? [Takt time planning - a good method for production in construction projects?] Master theses, Norwegian University of Science and Technology, Trondheim, Norway.

Solem, A. (2012). Involvering av bygg-/produksjonsleddet i prosjekteringsfasen. St. Olav's Hospital. Bygging av Kunnskapssenteret [Involving production in the design phase of St. Olavs Hospital. Building the Knowledge center] $1^{\text {st }}$ edition. Norwegian University of Science and Technology, Trondheim, Norway.

Velarde, G.J., Saloni, D.E., van Dyk, H., and Giunta, M. (2009). "Process flow improvement proposal using lean manufacturing philosophy and simulation techniques on a modular home manufacturer." Lean Constr. Journal, 5 (1) 77-93.

Yin, R. K., (2009). Case study research methods, $4^{\text {th }}$ Ed., SAGE Publications, Inc. New Delhi, India 
Matthias Helgi Gardarsson, Ola Laedre, and Fredrik Svalestuen

Proceedings IGLC - 27, July 2019, Dublin, Ireland 